\title{
A bi-faceted role of estrogen receptor $\beta$ in breast cancer
}

\author{
Etienne Leygue and Leigh C Murphy \\ Department of Biochemistry and Medical Genetics, Manitoba Institute of Cell Biology, University of Manitoba, \\ 675 McDermot Avenue, Winnipeg, Manitoba, Canada R3E 0V9
}

Correspondence should be addressed to E Leygue Email eleygue@cc.umanitoba.ca

\begin{abstract}
Despite over 15 years of research, the exact role, if any, played by estrogen receptor $\beta$ (ER $\beta$ ) in human breast cancer remains elusive. A large body of data both in vitro and in vivo supports its role as an antiproliferative, pro-apoptotic factor especially when co-expressed with ER $\alpha$. However, there is a smaller body of data associating ER $\beta$ with growth and survival in breast cancer. In clinical studies and most often in cell culture studies, the pro-growth and prosurvival activity of ER $\beta$ occurs in ER $\alpha$-negative breast cancer tissue and cells. This bi-faceted role of $E R \beta$ is discussed in this review.
\end{abstract}

\author{
Key Words \\ - estrogen therapy \\ - estrogen receptor \\ - breast \\ - endocrine therapy resistance
}

Endocrine-Related Cancer (2013) 20, R127-R139

\section{Introduction}

The critical role of estrogen in human breast cancer is undisputed. The practical consequences of the concept of inhibiting the mitogenic action of estrogen on breast cancer cells have been the successful establishment of the endocrine therapies for treating breast cancer (Trialists' 1992, 1998) as well as providing options for preventing breast cancer (Fisher et al. 2005). While the concept itself is relatively simple, our understanding of the exact molecular mechanisms by which estrogen is involved in these processes continues to evolve and is more complex and multifaceted than originally thought (Zwart et al. 2011). In particular, one critical discovery has been the identification of a second estrogen receptor (ER), called ER $\beta$ (Kuiper et al. 1996), in contrast to the classical $E R \alpha$, which can also mediate estrogen action in target cells. The discovery of ER $\beta$ has led to a full reevaluation of estrogen action in all target tissues, including human breast cancer (Fox et al. 2008). However, despite over 15 years of research, the exact role, if any, played by ER $\beta$ in human breast cancer remains elusive (Fox et al. 2008, Thomas \& Gustafsson 2011, Murphy \& Leygue 2012). Several reviews have recently covered the general topic of ER $\beta$ and tumorigenesis (Fox et al. 2008, Leygue \& Murphy 2011, Thomas \& Gustafsson 2011, Leung et al. 2012, Murphy \& Leygue 2012). However, emerging data suggest that ER $\beta$ may have a bi-faceted role in breast cancer. We herein discuss the most recent data which suggest that ER $\beta$ plays a bi-faceted role in breast cancer. Interestingly, a bi-faceted role of ER $\beta$ in gynecological cancer (ovarian vs endometrial) has also been suggested (Haring et al. 2012).

ER $\beta$ has several variant isoforms, and generally, it is the ligand-binding form, ER $\beta 1$, that is being referred to. The variant ER $\beta$ protein isoforms derive from alternatively spliced transcripts that result in C-terminally truncated proteins that cannot bind ligand. Often the antibodies used for immunohistochemistry recognize epitopes that are common to all variant proteins and cannot distinguish among them. In this review, when this is the case, the terminology used is total ER $\beta$ or ER $\beta$-like proteins. When an isoform-specific antibody is used, then the actual isoform name, e.g. ER $\beta 1$, is used.

\section{What is meant by a bi-faceted role for ER $\beta$ ?}

The majority of published data have concluded that ER $\beta 1$ has both antiproliferative and pro-apoptotic activities,

Published by Bioscientifica Ltd. 
while a smaller number of studies suggest a proliferative and survival role for ER $\beta 1$. Therefore, the possibility of a bi-faceted role for ER $\beta 1$ in breast cancer development and progression can be suggested. The following will review both clinical and experimental data that support a bi-faceted role for ER $\beta 1$ in breast cancer.

\section{Clinical correlation studies supporting the bi-faceted role of ER $\beta$ in breast cancer}

There are several studies supporting a bi-faceted role of ER $\beta$, in particular ER $\beta 1$, obtained using retrospective correlative biomarker analyses in cohorts of breast cancer cases linked to clinical outcome information. We have only considered studies in which ER $\beta$-like proteins have been measured. Furthermore, these studies (except in one case where western blotting was used) also used immunohistochemistry, such that ER $\beta$ expression only in tumor cells was measured. These studies have been recently reviewed by us and others (Fox et al. 2008, Leygue \& Murphy 2011, Leung et al. 2012, Murphy \& Leygue 2012) in detail. A consistent finding is that, in contrast to $\mathrm{ER} \alpha$, total ER $\beta$ levels decline during breast tumorigenesis (Leygue et al. 1998, Roger et al. 2001), a phenomenon also observed in other cancers such as prostate (Prins \& Korach 2008), colon, ovary, and lung (Bardin et al. 2004) but not endometrial cancer (Haring et al. 2012). This supports a potential tumor-suppressor role. Generally, higher levels of ERß-like expression were found associated with the expression of good prognostic markers or better clinical outcome, usually in patients who have subsequently been treated with tamoxifen (Esslimani-Sahla et al. 2004, Fleming et al. 2004, Gruvberger-Saal et al. 2007). Other studies have, however, found that high vs low expression of ER $\beta$-like proteins have either no (Esslimani-Sahla et al. 2004, Miller et al. 2006, Skliris et al. 2006, Honma et al. 2008, Shaaban et al. 2008) or poor (Saji et al. 2002a,b, O'Neill et al. 2004, Novelli et al. 2008, Shaaban et al. 2008) prognostic value in breast cancer.

Differences observed are potentially related to whether or not ER $\beta$ is expressed alone or co-expressed with ER $\alpha$. It should be remembered that ER status (positive or negative) in human breast cancer is only defined by the measurement of ER $\alpha$ (Hammond et al. 2010). Approximately, $59 \%$ of primary breast cancers show ER $\beta$ co-expressed with $\mathrm{ER} \alpha(\mathrm{ER} \beta+/ \mathrm{ER} \alpha+)$ (Murphy et al. $2003)$ and $\sim 17 \%$ only express $\operatorname{ER} \beta$ (ER $\beta+/ \operatorname{ER} \alpha-)$ (Murphy et al. 2003). Usually, only ER + patients are treated with endocrine therapy and ER + status is itself determined only by ER $\alpha$. Therefore, most tumors being assessed in the majority of previous studies would be those co-expressing ER $\beta 1$ or total ER $\beta$ proteins with ER $\alpha$. Furthermore, in most but not in all these studies, higher levels of ER $\beta 1$ or total ER $\beta$ proteins together with ER $\alpha$ are a better predictor of endocrine responsiveness than $E R \alpha$ alone. This supports the idea that nuclear ER $\beta$-like proteins are having a restraining action on ER $\alpha$-mediated growth and survival activities. However, in three studies where the cohorts studied were $\mathrm{ER} \alpha$ negative and the patients had been subsequently treated with tamoxifen, high ER $\beta 1$ levels were predictive of a good response to tamoxifen therapy (Gruvberger-Saal et al. 2007, Honma et al. 2008, Yan et al. 2013). One of these studies (Yan et al. 2013) was a randomized placebo-controlled clinical trial, in which benefit was only found in the tamoxifen-treated but not in the placebo arm; therefore providing evidence that ER $\beta$ expression was predictive for response to tamoxifen inhibition of tumor growth and survival. These correlative data, together with the previous observations of a positive correlation of ER $\beta 1$ expression with Ki67 (a marker of proliferation), support the idea that ER $\beta 1$ is driving proliferation and/or survival in a subgroup of patients whose tumors were ER $\alpha$ negative. This subgroup seemed to be defined also by a high expression of a potential modulator of ER $\beta$ activity, called steroid receptor RNA activator protein (Yan et al., 2013). This ER co-regulator is encoded by a gene that in its own right is also bi-faceted, as alternative splicing of its transcripts results in a functional non-coding RNA and/or a protein able to modulate transcription (Cooper et al. 2011).

Another important finding, in one (Honma et al. 2008) of the three studies referred to the above, is that high expression of ER $\beta 1$ in triple-negative breast cancer cases was also significantly associated with good clinical outcome in patients treated with tamoxifen. While this may explain the historical observations that a small subset of patients with apparently ER $\alpha$-negative breast cancers respond to tamoxifen treatment (von Maillot et al. 1980, Stewart et al. 1982), an implication of these findings is that ER $\beta 1$ may be a viable treatment target in some triplenegative breast cancers. Therefore, a group of patients previously considered only for aggressive chemotherapies would now be candidates for better tolerated hormonallike therapies.

\section{Experimental studies supporting a bi-faceted role of ER $\beta$}

In normal mammary tissue, ER $\beta$ is the most widely expressed ER and is expressed in both luminal and myoepithelial cells as well as in some cells in the

Published by Bioscientifica Ltd 
surrounding stroma. ER $\alpha$, in contrast, is less frequently expressed and generally its expression remains confined to the luminal epithelial compartment (Speirs et al. 2002). $E R \alpha$, however, appears to play a more important role in the normal mammary gland. Indeed, knockout Er $\alpha$ mice do not develop a functional mammary gland (Bocchinfuso \& Korach 1997, Feng et al. 2007), whereas knockout $\operatorname{Er} \beta$ animals undergo an overall normal mammary gland development. Subtle effects associated with decreased differentiation and increased proliferation in the alveoli of lactating mammary glands are sometimes observed in these mice; these changes appear to be age related and are only observed in some (Forster et al. 2002, Palmieri et al. 2002), but not all, $\operatorname{Er} \beta$ knockout mouse models (Couse \& Korach 1999, Antal et al. 2008). Furthermore, it has been suggested that the effect on the development of the mammary gland might be indirect due to a deficiency in ovarian hormone synthesis rather than a direct result of lack of ER $\beta$ expression in breast epithelial cells (Antal et al. 2008). Data generated in vitro, on rodent or human mammary epithelial cells (nontumorigenic as well as neoplastic) in culture, showed that shutting down ER $\beta$ expression leads to an increased ligand-dependent and -independent growth (Helguero et al. 2005, Treeck et al. 2010). These results are consistent with the observed increased proliferation of cells in in vivo models following knockdown of $E R \beta$ expression (Weihua et al. 2000, Forster et al. 2002, Paruthiyil et al. 2004).

In apparent contrast to the common conclusion that ER $\beta 1$ is an inhibitor of proliferation, treatment of ovariectomized mice for $48 \mathrm{~h}$ with a selective agonist of ER $\beta 1$ called BAG has led, in the mammary epithelial cells of treated mice, to increased bromodeoxyuridine labeling (Cheng et al. 2004a). Interestingly, this incorporation, a marker of renewed DNA synthesis, was similar to that observed when mice were treated with $17 \beta$-estradiol $\left(\mathrm{E}_{2}\right)$ and tamoxifen but was not observed in uterine cells (Cheng et al. 2004a). As such, ER $\beta$ appeared to mediate cell proliferation in a tissue-specific way. Colocalization of Ki67 and ER $\beta$ in $\sim 47 \%$ of mammary epithelial cells in primates has also been reported (Cheng et al. 2005). Such colocalization (Saji et al. 2000, Cheng et al. 2005) suggested that ER $\beta 1$ has a role, although not essential, in proliferation of some normal mammary epithelial cells. Or at least under specific circumstances, ER $\beta$ does not inhibit proliferation.

In most but not all studies where ER $\beta 1$ has been overexpressed in cell lines, antiproliferative and proapoptotic (Lazennec et al. 2001, Cheng et al. 2004b) activity was observed (Paruthiyil et al. 2004; Table 1).
And intestinal tumorigenesis is enhanced in mice resulting from crosses between Apc (min) mice and ER $\beta$ deficient mice (Giroux et al. 2008, Cleveland et al. 2009). ER $\beta 1$ can inhibit epithelial to mesenchymal transition in cancer cells (Mak et al. 2010, Thomas et al. 2012), consistent with a role in epithelial differentiation. More insight into the molecular mechanisms by which this occurs has recently been published using immortalized prostate epithelial and prostate cancer cell line models (Mak et al. 2013). Furthermore, it was also shown that these effects were mediated by a selective androgenderived ligand for ER $\beta 5 \alpha$-androstane, $3 \beta, 17 \beta$-diol, and not estrogen (Mak et al. 2013). Altogether, these data support a role for ER $\beta$ as an anti-growth, pro-apoptotic, and pro-differentiation factor.

Interestingly, the development of a few breast cancer cell line models, where increased ER $\beta 1$ expression was associated with increased proliferation and survival, supported the idea that under some circumstances ER $\beta 1$ can associate with proliferation instead of apoptosis. These findings, however, may be due to alternative posttranslational modifications, i.e. short vs long (N-terminal) forms of ER $\beta 1$, a distinct cellular circuitry background associated with ER $\alpha$ negativity, clonal selection artifacts, and/or an insertional mutagenesis phenomenon of the transfected construct. The p53 status of cells may also affect ER $\beta 1$ activity (Choi \& Pinto 2005, Lewandowski et al. 2005, Skliris et al. 2007) as might the microenvironment, and whether or not the cells are grown in a $2 \mathrm{D}$ vs $3 \mathrm{D}$ structure. Such differences alone or in combination could contribute to the bi-faceted nature of ER $\beta$. Cotrim et al. 2012) recently published results, where they found that ER $\beta$ agonists as well as ER $\alpha$ selective ligands induced mammary gland hyperplasia and increase tumor growth of mice in which MC4-L2 mammary tumor cells had been implanted. This was in stark contrast to the MC4-L2 mouse mammary tumor cell model when grown under 2D cell culture conditions. MC4-L2 cells endogenously express both ER $\alpha$ and ER $\beta 1$. Under 2D culture conditions, selective ligands for ER $\alpha$ stimulate proliferation whereas selective ligands for ER $\beta$ have little effect on proliferation but instead increase apoptosis, increase p53 expression, and decrease cell numbers. However, when the cells are grown in Matrigel 3D culture, the ER $\beta$ agonists exert a slight but significant increase in cell numbers, which was inhibited by co-incubation with the MEK inhibitor U0126. It was hypothesized that activation of erk1/2 MAPK signaling by Matrigel, a surrogate for basement membrane, fully blocked the growth-inhibitory effects resulting from ER $\beta 1$ activation by agonist ligands (Cotrim et al.

Published by Bioscientifica Ltd 
Table 1 Cell line models of human ER $\beta$ overexpression.

\begin{tabular}{|c|c|c|c|c|c|}
\hline Cell line & $E R \beta$ isoform & $\begin{array}{l}\text { Constitutive vs } \\
\text { inducible }\end{array}$ & $\begin{array}{l}\text { ER } \alpha \\
\text { expression }\end{array}$ & Phenotype & Reference \\
\hline \multicolumn{6}{|l|}{ Growth inhibition } \\
\hline MCF7 & $\mathrm{ER} \beta 1$ & $\begin{array}{l}\text { Constitutive } \\
\text { (adenoviral } \\
\text { transient) }\end{array}$ & Yes & $\begin{array}{l}\text { Reduced } E_{2} \text { growth in cells in } \\
\text { culture and xenograft }\end{array}$ & Paruthiyil et al. (2004) \\
\hline Tet-off-T47D & $\mathrm{ER} \beta 1$ & Inducible & Yes & Reduced $\mathrm{E}_{2}$-induced growth & Strom et al. (2004) \\
\hline MCF7 & $\mathrm{ER} \beta 1$ & $\begin{array}{l}\text { Constitutive } \\
\text { (adenoviral } \\
\text { transient) }\end{array}$ & Yes & $\begin{array}{l}\text { Ligand-independent cell cycle } \\
\text { arrest }\end{array}$ & Paruthiyil et al. (2011) \\
\hline Tet-on MCF7 & $\mathrm{ER} \beta 1$ & Inducible & Yes & $\begin{array}{l}\text { Reduced } E_{2} \text { growth Increase } \\
\text { sensitivity to tamoxifen }\end{array}$ & Murphy et al. (2005) \\
\hline Tet-off MCF7 & $\mathrm{ER} \beta 2 / \mathrm{cx}$ & Inducible & Yes & $\begin{array}{l}\text { Reduced } E_{2} \text { transcription, } \\
\text { reduced } P R \text {, and growth ND }\end{array}$ & $\begin{array}{l}\text { Saji et al. (2002b) and } \\
\text { Zhao et al. (2007) }\end{array}$ \\
\hline Tet-off MCF7 & $\mathrm{ER} \beta 1$ & Inducible & Yes & $\begin{array}{l}\text { Reduced } \mathrm{E}_{2} \text { growth Increase } \\
\text { sensitivity to antiestrogens }\end{array}$ & $\begin{array}{l}\text { Hodges-Gallagher et al. } \\
\text { (2008) }\end{array}$ \\
\hline Tet-on HEK293 & $\mathrm{ER} \beta 2 / \mathrm{cx}$ & Inducible & No & $\begin{array}{l}\text { Reduced } \mathrm{E}_{2} \text { transcription, } \\
\text { growth ND }\end{array}$ & Zhao et al. (2007) \\
\hline Tet-off MCF7 & $\mathrm{ER} \beta 1$ & Inducible & Yes & $\begin{array}{l}\text { Reduced basal and } \mathrm{E}_{2} \text {-induced } \\
\text { growth }\end{array}$ & Liu et al. (2008) \\
\hline MDA-MB-231 & $\mathrm{ER} \beta 1$ & Constitutive & No & $\begin{array}{l}\text { Growth inhibition - ligand } \\
\text { independent }\end{array}$ & Lazennec et al. (2001) \\
\hline Hs578T & $\mathrm{ER} \beta 1$ & Tet-on inducible & No & Reduced $\mathrm{E}_{2}$-induced growth & Secreto et al. (2007) \\
\hline Hs578T & $\mathrm{ER} \beta 2 / \mathrm{cx}$ & Tet-on inducible & No & No effect on growth & Secreto et al. (2007) \\
\hline Hs578T & $\mathrm{ER} \beta 1$ & Tet-on inducible & No & Reduced $\mathrm{E}_{2}$-induced growth & Shanle et al. (2011) \\
\hline \multicolumn{6}{|l|}{ No effect on growth } \\
\hline MDA-MB-231 & $\mathrm{ER} \beta 1$ & Constitutive & No & $\begin{array}{l}\text { No effect alone, but sensitized } \\
\text { to RA inhibition }\end{array}$ & Rousseau et al. (2004) \\
\hline Tet-on-MDAMB231 & $\mathrm{ER} \beta 1$ & Inducible & No & No effect on proliferation & Murphy \\
\hline Tet-on-MDA-MB-231 & $\mathrm{ER} \beta 2 / \mathrm{cx}$ & Inducible & No & No effect on proliferation & Murphy \\
\hline MCF-7 & $\mathrm{ER} \beta 1$ & Constitutive & Yes & $\begin{array}{l}\text { No effect on } E_{2} \text {-induced } \\
\text { growth. Increases sensitivity } \\
\text { to endoxifen }\end{array}$ & Wu et al. (2011) \\
\hline \multicolumn{6}{|l|}{ Growth stimulation } \\
\hline MDA-MB-231 & Short ER $\beta 1$ & Constitutive & No & Proliferation & Tonetti et al. (2003) \\
\hline MDA-MB-435 & $\mathrm{ER} \beta 1$ & Constitutive & No & $\begin{array}{l}\text { Increased proliferation and } \\
\text { invasion }\end{array}$ & Hou et al. (2004) \\
\hline
\end{tabular}

RA, retinoic acid; ND, not determined.

${ }^{a}$ This is now known to be a melanoma-derived cell line (Rae et al. 2007).

${ }^{b}$ Murphy LC, Ung K \& Peng B 2005, unpublished observations.

(2012). The authors also went on to show that when mammary epithelial cells, either normal-like or neoplastic, were grown in $2 \mathrm{D}$ culture in the presence of EGF (which activated erk1/2), ER $\beta$ agonists increased cell numbers. In a background of activated erk1/2, further experiments also implicated a role for activated PI3K/Akt signaling in this ER $\beta$-driven proliferation. As ER $\beta$ phosphorylation was enhanced under conditions of growth stimulation, it was speculated that this posttranslational alteration may also play a role in ER $\beta$-induced proliferation.

The results described earlier are the basis for suggesting a bi-faceted role of ER $\beta$ in breast cancer growth and survival. Furthermore, they also provide some insight into the potential mechanisms underlying a bi-faceted role.

\section{What are possible mechanisms of the bi-faceted activity of ER $\beta$ ?}

To assess the potential processes underlying this bi-faceted aspect of ER $\beta$ 's personality, it is helpful to outline briefly what is known about the structure and mechanism of action of this ligand-regulated transcription factor. ER $\alpha$ and ER $\beta$ belong to the thyroid/steroid receptor superfamily. As shown in Fig. 1, these receptors share the same structural and functional composition: an N-terminal functional domain (AF1), able to activate transcription 


\begin{tabular}{|c|c|c|c|c|c|c|c|}
\hline \multirow[t]{2}{*}{ mRNA } & 1 & 2 & 3 & 4 & 5 & 6 & 8 \\
\hline & & 148 & 214 & 304 & & & 500530 \\
\hline \multirow[t]{2}{*}{ Protein } & $A / B$ & & c & D & & $E$ & $\mathrm{~F}$ \\
\hline & $\mathrm{AF} 1$ & & BD & & & 2/L & \\
\hline
\end{tabular}

\section{Figure 1}

RNA and protein structure of ER $\beta$. Exonic structure of ER $\beta$ messenger is indicated in blue boxes. The protein shares the classical structure of other steroid receptors with structural domains A-F shaded in various shades of pink. The positions of the functional domains, activation function 1 (AF-1), DNA-binding domain (DBD), activation function 2 (AF2), and ligandbinding domain (LBD) are indicated in red.

in the absence of ligand, a DNA-binding domain (DBD), consisting of a classical zinc-fingers motif, and a C-terminal functional domain (AF2), activated by the binding of estrogen on the ligand-binding domain (LBD). Several excellent reviews have described how these receptors can act (McKenna et al. 1999, Lonard et al. 2007, Kumar \& McEwan 2012). Briefly, several mechanisms of action have been described. The first one, referred to as 'classical', is simplistically described in Fig. 2. In this model, the ligand enters passively into the target cells, binds to the receptor, and initiates a cascade of wellcharacterized events. The receptor is first released from a cytoplasmic chaperone complex containing several proteins including heat-shock proteins 70 and 90 . The freed receptor, subjected to subsequent posttranslational events including multiple phosphorylations (Le Romancer et al. 2011), enters the nucleus, dimerizes, and binds to defined genomic enhancer regions, containing specific motifs known as estrogen-responsive elements (EREs). This binding is followed by the recruitment of cofactors, positive (coactivators) or negative (corepressors), the balance of which leads to either the activation or the repression of the expression of involved genes.

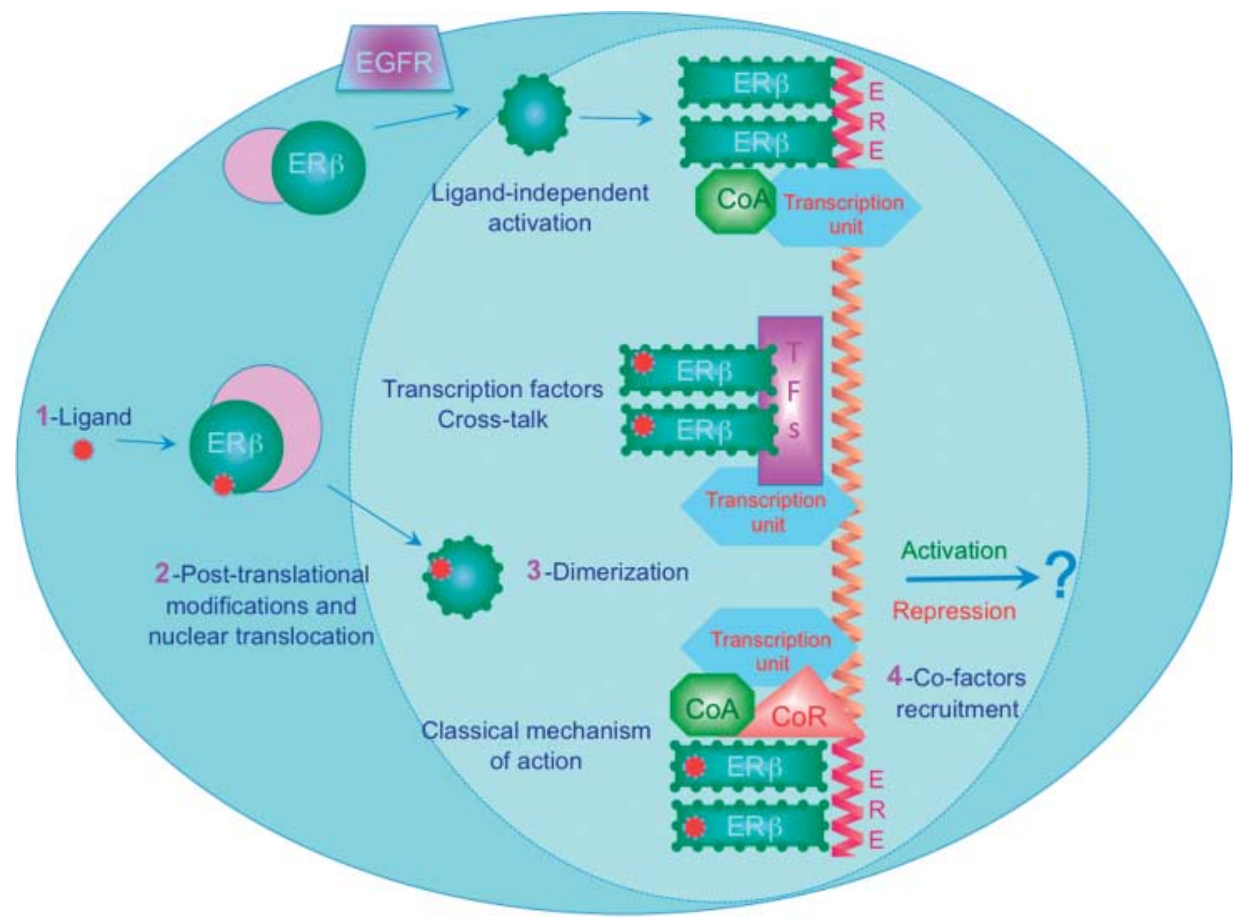

\section{Figure 2}

Simplified representation of three potential ER $\beta$ mechanisms of action. 'Classical' mechanism (lower part of the diagram): activation of ER $\beta 1$ occurs in four steps. First, the ligand penetrates passively in the target cells through the plasma membrane and binds to the receptor, inducing the release from a cytoplasmic chaperone complex (pink). This release is followed by a cascade of posttranslational modifications (indicated by dots on the surface of the receptor) and the targeting of the receptor to the nucleus. The receptor is then able to form dimers (homodimers or heterodimers with $\mathrm{ER} \alpha$ ), which binds specific enhancer regions (estrogenresponsive element, ERE) upstream or downstream of target genes.
Depending on the ligand involved and the overall conformation of the receptors recruited, dimers will then interact with positive (coactivator, green) or negative (corepressors, red) regulators, leading to the activation or the repression of specific target genes. Tethering mechanism (middle part of the diagram): activated receptor can bind to transcription factors (such as AP-1) and modulate, positively or negatively, the activity of these factors. Unliganded activation (top part of the diagram): the receptor can be activated by posttranslational modification; phosphorylations resulting from EGFR signaling cascade, for example. Activated receptor can then act through ERE or tethering mechanism. http://erc.endocrinology-journals.org DOI: 10.1530/ERC-12-0389
(C) 2013 Society for Endocrinology Printed in Great Britain 
This estrogenic action has been found to be cell-, gene-, and context specific. As outlined in previous reviews (McKenna et al. 1999, Lonard et al. 2007, Zwart et al. 2011, Kumar \& McEwan 2012), the resulting effect on gene transcription is a dynamic process, involving multiple protein complexes, which contain chromatin-modifying molecules such as histone deacetylases, protein degradation units involving proteasome and ubiquitin ligase, as well as splicing regulatory units. Nonclassical mechanisms of action have also been described for steroid receptors: these include activation by EGF signaling through ligandindependent phosphorylations of the receptor; tethering of the receptor with other transcription factors, such as Sp1 and AP1 (Hall et al. 2001; Fig. 2); and non-genomic action involving receptors located on the cell membrane (Hammes \& Levin 2011). Overall, the action of the ER $\beta$ will mechanistically depend on many parameters including but not limited to cyclical interactions between regulatory molecules (ligand, cofactors, ubiquitin, or histone deacetylases), cell context, specific protein degradation (proteasome involvement), and the exact gene considered (McKenna et al. 1999, Lonard et al. 2007, Kumar \& McEwan 2012). Most of all, as with all other biological processes, the specific observation of a particular ER $\beta$ effect will depend on what endpoint is looked at and most importantly how it is observed. With that in mind, the bi-faceted aspect of ER $\beta$ action detailed earlier could result from differential modification and/or regulation of any of the steps involved in the mechanisms outlined earlier.

\section{Ligand-dependent and -independent activity}

First, the endogenous ligands able to bind and potentially regulate ER $\beta 1$ action are multiple (Kuiper et al. 1998, Guerini et al. 2005, Michael Miller et al. 2012) and their respective effects, in a tissue-specific context, remain to be fully characterized (Thomas \& Gustafsson 2011). Even if ER $\beta 1$ is 'officially' defined as being an estrogen-binding protein, reports also indicate that compounds such as phytoestrogens (Shanle \& Xu 2010, Shanle et al. 2011) DHEA (Michael Miller et al. 2012) and oxysterols (DuSell \& McDonnell 2008) can also modulate the activity of this receptor. Importantly, some of these different ligands preferentially activate ER $\beta$ compared to ER $\alpha$ (Shanle \& Xu 2010) and may alter the ER homo- and heterodimerization profiles (Powell et al. 2012). As such, one can easily see that such ligands can interfere with the 'normal or classical' pathway this receptor is otherwise directed toward.

\section{ERß variations}

Alternatively spliced variants $\quad E R \beta$ variant isoforms can be an important factor (Herynk \& Fuqua 2004). Indeed, as previously emphasized, immunodetection implies the recognition of a specific epitope within a protein. Therefore, only a portion of the molecule is recognized, independently of the integrity of the whole protein. The characterization of multiple variants, mainly generated through alternative splicing (Figs 3 and 4), increases the complexity of interpreting the information gathered using one antibody for immunodetection of $\mathrm{ER} \beta$ expression. Indeed, an antibody raised against the $N$-terminal extremity of the ER $\beta$ receptor will not differentiate between the full-length ligand-binding ER $\beta 1$ and a variant encoded by a well-characterized RNA, called ER $\beta 2 / c x$. ER $\beta 2 / c x$ has an alternate exon 8 and encodes a protein missing the LBD. As such detecting the expression of this molecule, unable to bind ligand, but also able to heterodimerize with wild-type $\mathrm{ER} \beta 1$ and $\mathrm{ER} \alpha$, could lead to erroneous interpretation (Murphy \& Watson 2006).

Five major variants (ER $\beta 1-5)$, resulting from alternative splicing events involving exons 7 and 8 , have been identified (Fig. 3). ER $\beta 1$ (the first described), 2/cx, 3, and 4 variants contain exons $1-7$ of the human $E R \beta$ gene followed by one of the several alternative exon 8 . ERß5 variant contains an extended exon 7 and its exon 8 results from the splicing of an intron containing atypical CC and CA donor and acceptor sites.

The exact function of the alternatively spliced ER $\beta$ variants remains unclear and contradictory results concerning potential function have been published (Ogawa et al. 1998, Peng et al. 2003, Leung et al. 2006). For example, transient expression studies show that ER $\beta 2 / c x$ cannot bind ligand and when overexpressed can inhibit ER $\alpha$ transcriptional activity (Ogawa et al. 1998, Peng et al. 2003), with little effect on ER $\beta 1$ activity. However, subsequent studies have shown that ER $\beta 2 / \mathrm{cx}$ as well as the other C-terminally truncated variants, ER $\beta 3,4$, and 5 , all of which cannot bind ligand and are missing the coactivator recruiting helix 12 (Fig. 4), can heterodimerize with ER $\beta 1$ and enhance its estrogen-mediated transcriptional activity (Leung et al. 2006). The differences in published results may be in part due to the different cell lines used to undertake these transient expression studies as well as different levels of expression and relative expression achieved. An overarching conclusion, however, is that the variant ER $\beta$ isoforms can modify both ER $\alpha$ and ER $\beta 1$ activity when co-expressed. Therefore, differential expression of the ER $\beta$ variants may play a role

Published by Bioscientifica Ltd. 
(a)

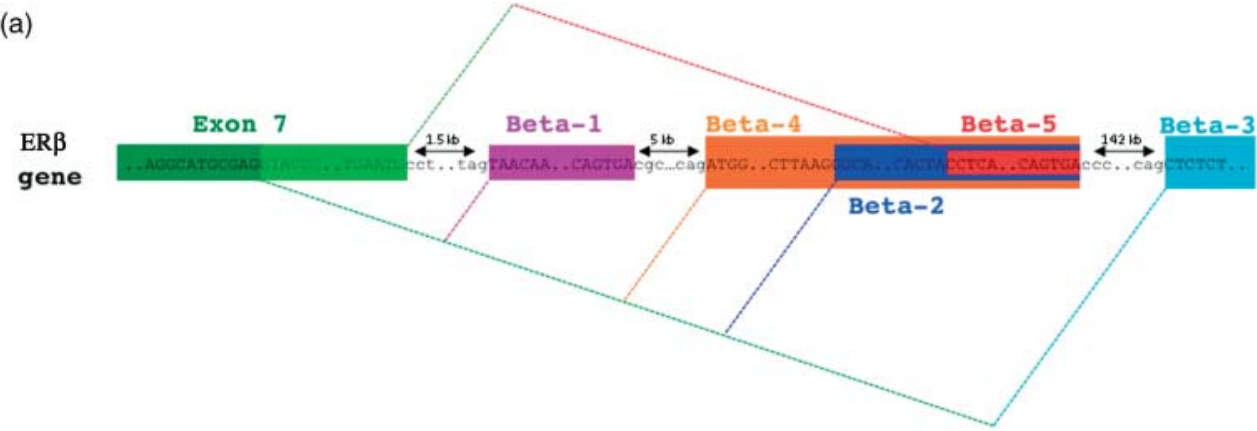

(b)

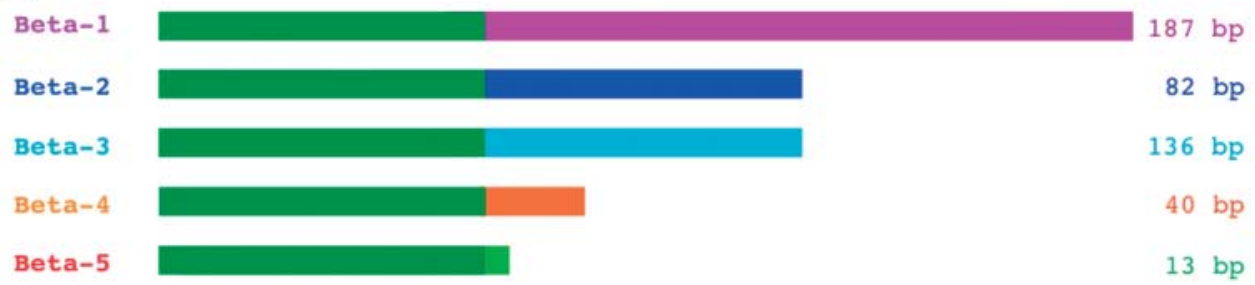

Figure 3

Schematic representation of alternative splicing events resulting in the production of multiple ER $\beta$ isoforms. (A) The use of alternative acceptor sites leads to the production of $E R \beta 1,-2 / c x,-3$, and $\beta 4$ mRNAs. Indeed, these isoforms share a common exon 7 (exon 7 b1-4, dark green) but differ in their alternative exon 8 (purple, dark blue, light blue, and orange respectively). The combined use of alternative donor and acceptor sites

in altered and bi-faceted $\operatorname{ER} \beta$ action and sensitivity to antiestrogens during breast tumorigenesis and breast cancer progression.

$E R \beta 1,-2 / c x,-3$, and -5 mRNAs have been detected in breast cancer tissues and cell lines. Using a specific assay allowing the co-amplification of ER $\beta 1,2 / \mathrm{cx}$ and 5 , we found that not only breast cancer cell lines expressed different relative levels of these variants but also an increase in ER $\beta$ 2/cx and 5 RNA isoforms relative to the ER $\beta 1$ RNA isoform occurs during breast tumorigenesis (Leygue et al. 1999). produces $E R \beta$ mRNA, which contains an extended exon 7 (light green) and a shorter exon 8 (red). (B) Schematic representation of resulting common exon 7 (green) and additional coding sequences brought by the respective exon 8: purple, dark blue, light blue, and orange for exon 8 of ER $\beta 1,-\beta 2 / c x$, $-\beta 3$, and $-\beta 4$ respectively. The length of additional respective coding sequence is indicated on the right.

Co-expression with ER $\alpha$ The heterodimerization of ER $\beta 1$, as well as the proteins encoded by its known splicing variants, with $\mathrm{ER} \alpha$, further increases the complexity of the potential effect these ER $\beta$-like proteins have on the estrogen-signaling pathway. Multiple articles have shown that homo- or heterodimers involving $\mathrm{ER} \beta$ and $\mathrm{ER} \alpha$ had significantly different gene targets (Monroe et al. 2005, Chang et al. 2006, Liu et al. 2008, Powell et al. 2012). The ability of ER $\beta$ variants to modify the activity of $E R \alpha$ is, per se, sufficient to drastically interfere with the expected mitogenic effect of estrogen on ER-positive cells as well as



\section{Figure 4}

Alignment of the C-terminal extremities of ER $\beta-1,-2 / c x,-3,-4$, and $\beta-5$ proteins. These isoforms are identical in their first 468 amino acids (aa) but differ in the sequence corresponding to the end of the ligand binding of Printed in Great Britain
(C) 2013 Society for Endocrinology
ER $\beta 1$. The total length of the resulting protein is shown on the right side. Underlined in ER $\beta 1$ sequence are the amino acid sequences involved in the ligand-binding domain of the receptor. 
to affect the sensitivity of the cells to antiestrogenic agents (Murphy et al. 2005, Wu et al. 2011).

Posttranslational modifications ERs are subject to multiple posttranslational modifications that may influence function (Le Romancer et al. 2011). It is well acknowledged that the presence of $\mathrm{ER} \alpha$ is important in terms of diagnosis and prediction of response to endocrine therapy such as tamoxifen. More recently, it was shown that the specific phosphorylation profile of $E R \alpha$, i.e. the specific detection of multiple phosphorylated residues (Skliris et al. 2010), might be a more accurate way to assess its prognostic and predictive value. It is easy to extrapolate that the same will happen regarding specific ER $\beta$ phosphorylation (Hamilton-Burke et al. 2010). Other posttranslational modifications of ER $\beta$ have recently been reviewed (Le Romancer et al. 2011) and another ER $\beta$ variant, an N-terminally truncated short form of ER $\beta 1$ generated posttranslationally by proteolysis (Savinov et al. 2006), has also been identified. The shorter ER $\beta 1$ protein may be more stable than the long form as it is potentially missing the binding site for the ubiquitin ligase, carboxyl terminus of HSC70-interacting protein (CHIP), required for inducing ERß1 proteasomal degradation (Tateishi et al. 2006). Functional differences between the long and short forms of ER $\beta 1$ have been described, in particular associated with anti-inflammatory activities of ER $\beta 1$ (Bhat et al. 1998, Tateishi et al. 2006, Cvoro et al. 2008, Saijo et al. 2011). Furthermore, it has been shown that Pescadillo ribosomal biogenesis factor 1 (PES1) differentially affects ER $\beta 1$ and $E R \alpha$ at a posttranslational level and may, in part, be responsible for the altered ratios of $\operatorname{ER} \alpha / \operatorname{ER} \beta$ seen consistently during breast tumorigenesis (Cheng et al. 2012, Thomas \& Gustafsson 2012). The short form of ER $\beta 1$ may not be regulated by PES1 in the same way as the long form.

Therefore, differential posttranslational modifications may affect ER $\beta 1$ function including specific degradation pathways (Sanchez et al. 2010, 2012, Cheng et al. 2012, Picard et al. 2012) and kinetics of turnover, involving particular heterodimers for example, and contribute to a bi-faceted mechanism of action.

Nuclear vs non-nuclear activity The similarities and differences of ER $\beta 1$ and ER $\alpha$ with respect to structure of the full-length ligand-binding forms and their respective variant isoforms have recently been reviewed (Thomas \& Gustafsson 2011, Murphy \& Leygue 2012). The similarity of ER $\beta 1$ to ER $\alpha$ has led to a focus on its mechanism of action as a transcription factor and therefore on its localization to the nucleus. However, an extranuclear localization of ER $\beta$ has been reported in some cells and tissues including breast cancer (Hamilton-Burke et al. 2010, Leung et al. 2012, Razandi et al. 2012). The functions and potential mechanisms of action at the extranuclear sites are being explored. They are, however, less well described than the function and mechanisms of action of nuclear ER $\beta$.

Similar to $\mathrm{ER} \alpha$, and other steroid hormone receptors, ER $\beta 1$ can homodimerize and directly bind to DNA sequences known as EREs, both distal and proximal, in target genes and regulate transcription. Four publications to date document genome binding (cistrome) studies of overexpressed ER $\beta 1$ in MCF7 breast cancer cells in culture (Liu et al. 2008, Charn et al. 2010, Zhao et al. 2010, Grober et al. 2011). These studies differ somewhat in their conclusions, although a common finding is that a reasonable degree of overlap exists between the cistrome of ER $\beta 1$ and ER $\alpha$ at least in MCF7 cells. Some differences were, however, noted, depending on the treatment conditions used. However, the transcriptional outcome of ER $\beta 1$ promoter binding compared to ER $\alpha$ often differs significantly as shown by transcriptome analyses (Chang et al. 2006, Vivar et al. 2010). Analysis of the ER $\beta 1$ target sequences within the genome identified ERE or half ERE binding sites as generally enriched, but each of the studies identifies distinct enrichment of other motifs not ERE related. The reasons for the differences, in these as well as those studies looking only at gene expression changes, may be due to the different experimental design: for example, in some cases, stable inducible overexpression of ERß1 in MCF7 (Liu et al. 2008, Zhao et al. 2010) or T47D (Williams et al. 2008) cells was used, another used stable overexpression of ER $\beta 1$ in MCF7 cells (Grober et al. 2011) and others used transient adenoviral mediated ER $\beta 1$ overexpression (Paruthiyil et al. 2004, Chang et al. 2006, Charn et al. 2010). Furthermore, the resulting levels of ER $\beta 1$ overexpression may differ significantly among the studies. One study in particular found that when using a ChIP-on-chip approach to map ER $\beta 1$ genome-wide binding in MCF7 cells overexpressing ER $\beta 1$, around $60 \%$ of the identified genomic binding sites contained AP-1-like binding regions associated with ERE-like sites (Zhao et al. 2010). Differential signaling through AP-1 by ER $\beta$ and $\mathrm{ER} \alpha$ has been reported (Paech et al. 1997). It is known that alterations in signaling pathways that impact directly on the ER and/or alternative transcription factor binding partners can also significantly alter the genome-wide binding of ER and estrogen signaling (Bhat-Nakshatri et al. 2008). As well other nuclear receptors, such as

Published by Bioscientifica Ltd 
androgen, ER-related, and progesterone receptors, can be expressed variably in the different cell line models used (Muscat et al. 2013). Recently, it has been suggested that there may be overlapping transcriptomes and possibly cistromes for some of these receptors and $\mathrm{ER} \alpha$ (Ni et al. 2011, Hickey et al. 2012, Deblois \& Giguere 2013). Therefore, altered genome-wide binding resulting in altered transcriptomes due to altered signaling cascades or differential backgrounds of other nuclear receptors may also underlie a bi-faceted activity of ER $\beta$ in specific cells.

More recently, accumulating data have brought into focus the possible role(s) of ER proteins outside of the nucleus in breast cancer (Levin 2012, Welsh et al. 2012). Rapid, non-genomic activities of estrogen are thought to be mediated by ERs localized to the plasma membrane on some target cells (Levin \& Pietras 2008). With respect to differential subcellular localization of ERß-like proteins, extranuclear vs nuclear localization has been reported to provide differential prognostic information at least in breast cancer in vivo (Shaaban et al. 2008, Yan et al. 2011). It is likely that ER $\beta$ located in mitochondria and identified to interact with several mitochondrial proteins (Nassa et al. 2011) may have a dual role in mediating tamoxifeninduced apoptosis through increased ROS (Razandi et al. 2012). This effect, seen in tamoxifen-sensitive breast cancer cell lines, did not occur in tamoxifen-resistant cells. In contrast, other studies found an association between mitochondrial ER $\beta$ expression and protection against radiation and UV-induced cell death (Harrington et al. 2003, Pedram et al. 2006). Such data also support a potential bi-faceted role of mitochondrial ER $\beta$-like proteins in apoptosis. In the first case, a pro-apoptotic role is likely, whereas in the latter cases, a protective role against cell death could be hypothesized. Differential localization of ER $\beta$ within the target cells may therefore also underlie altered function of ER $\beta$ as well as its variants.

\section{Summary/conclusions}

The importance of ER signaling pathways in breast cancer has been well established, with over 30 years of both basic and clinical research. Excitement surrounded the discovery of a second ER, ER $\beta$, in 1996, mainly due to a rising hope that elucidating its function and mechanism would shed light and bring answers to some of the major discrepancies seen between clinical observations and the established molecular understanding of estrogen signaling based upon the existence of only one receptor, ER $\alpha$. This excitement has now faded and stalled to some extent. There is no doubt significantly related to the dearth of cell model systems that naturally express detectable ER $\beta 1$ and/or its isoforms, as well as the use of less than wellcharacterized antibodies to detect a protein that is significantly downregulated in most types of immortalized or neoplastic cells.

However, the variability of results can also be explained in part, by the high degree of complexity that is emerging associated with the existence of ER $\beta$-like proteins. The discussion above also highlights some of the issues raised clinically by what we have called the bi-faceted role played by ER $\beta$ in breast cancer. Importantly, there are some mechanistic data currently emerging that shed light on the mechanisms involved and to support how this may occur.

The potentially profound impact of ER $\beta 1$ being a target for therapy in some ER-negative breast cancers where only few options apart from aggressive chemotherapies are available, as well as emerging new concepts for selectively delivering ligands to specific tissues (Finan et al. 2012), supports a continued focus on understanding the molecular mechanisms for the bi-faceted role of ER $\beta$.

Declaration of interest

The authors declare that there is no conflict of interest that could be perceived as prejudicing the impartiality of the review.

\section{Funding}

This work was supported by the Canadian Institutes of Health Research (CIHR), the CancerCare Manitoba Foundation (CCMF), the Canadian Breast Cancer Foundation (CBCF), the Canadian Breast Cancer Research Alliance (CBCRA), and the Manitoba Health Research Council (MHRC).

\section{References}

Antal M, Krust A, Chambon P \& Mark M 2008 Sterility and absence of histopathological defects in nonreproductive organs of a mouse ER $\beta$ null mutant. PNAS 105 2433-2438. (doi:10.1073/pnas.0712029105)

Bardin A, Boulle N, Lazennec G, Vignon F \& Pujol P 2004 Loss of ER $\beta$ expression as a common step in estrogen-dependent tumor progression. Endocrine-Related Cancer 11 537-551. (doi:10.1677/ erc.1.00800)

Bhat R, Harnish DC, Stevis P, Lyttle C \& Komm B 1998 A novel human estrogen receptor $\beta$ : identification and functional analysis of additional $\mathrm{N}$-terminal amino acids. Journal of Steroid Biochemistry and Molecular Biology 67 233-240. (doi:10.1016/S0960-0760(98)00115-0)

Bhat-Nakshatri P, Wang G, Appaiah H, Luktuke N, Carroll JS, Geistlinger TR, Brown M, Badve S, Liu Y \& Nakshatri H 2008 AKT alters genome-wide estrogen receptor $\alpha$ binding and impacts estrogen signaling in breast cancer. Molecular and Cellular Biology 28 7487-7503. (doi:10.1128/ MCB.00799-08)

Bocchinfuso W \& Korach K 1997 Mammary gland development and tumorigenesis in estrogen receptor knockout mice. Journal of Mammary Gland Biology and Neoplasia 2 323-334. (doi:10.1023/ A:1026339111278) http://erc.endocrinology-journals.org DOI: $10.1530 /$ ERC-12-0389
(C) 2013 Society for Endocrinology Printed in Great Britain 
Chang EC, Frasor J, Komm B \& Katzenellenbogen BS 2006 Impact of estrogen receptor $\beta$ on gene networks regulated by estrogen receptor $\alpha$ in breast cancer cells. Endocrinology 147 4831-4842. (doi:10.1210/ en.2006-0563)

Charn TH, Liu ET, Chang EC, Lee YK, Katzenellenbogen JA \& Katzenellenbogen BS 2010 Genome-wide dynamics of chromatin binding of estrogen receptors $\alpha$ and $\beta$ : mutual restriction and competitive site selection. Molecular Endocrinology 24 47-59. (doi:10.1210/me.2009-0252)

Cheng G, Weihua Z, Warner M \& Gustafsson J 2004a Estrogen receptors $\mathrm{ER} \alpha$ and $\mathrm{ER} \beta$ in proliferation in the rodent mammary gland. PNAS $\mathbf{1 0 1}$ 3739-3746. (doi:10.1073/pnas.0307864100)

Cheng J, Lee E, Madison L \& Lazennec G $2004 b$ Expression of estrogen receptor $\beta$ in prostate carcinoma cells inhibits invasion and proliferation and triggers apoptosis. FEBS Letters 566 169-172. (doi:10.1016/ j.febslet.2004.04.025)

Cheng G, Li Y, Omoto Y, Wang Y, Berg T, Nord M, Vihko P, Warner M, Piao Y \& Gustafsson J 2005 Differential regulation of estrogen receptor (ER) $\alpha$ and ER $\beta$ in primate mammary gland. Journal of Clinical Endocrinology and Metabolism 90 435-444. (doi:10.1210/jc.2004-0861)

Cheng L, Li J, Han Y, Lin J, Niu C, Zhou Z, Yuan B, Huang K, Jiang K, Zhang H et al. 2012 PES1 promotes breast cancer by differentially regulating ER $\alpha$ and ER $\beta$. Journal of Clinical Investigation 122 2857-2870. (doi:10.1172/ JCI62676)

Choi Y \& Pinto M 2005 Estrogen receptor $\beta$ in breast cancer: associations between ER $\beta$, hormonal receptors, and other prognostic biomarkers. Applied Immunohistochemistry \& Molecular Morphology 13 19-24. (doi:10.1097/00129039-200503000-00004)

Cleveland AG, Oikarinen SI, Bynote KK, Marttinen M, Rafter JJ, Gustafsson JA, Roy SK, Pitot HC, Korach KS, Lubahn DB et al. 2009 Disruption of estrogen receptor signaling enhances intestinal neoplasia in Apc(Min/+) mice. Carcinogenesis 30 1581-1590. (doi:10.1093/carcin/bgp132)

Cooper C, Vincett D, Yan Y, Hamedani MK, Myal Y \& Leygue E 2011 Steroid receptor RNA activator bi-faceted genetic system: heads or tails? Biochimie 93 1973-1980. (doi:10.1016/j.biochi.2011.07.002)

Cotrim CZ, Fabris V, Doria ML, Lindberg K, Gustafsson JA, Amado F, Lanari C $\&$ Helguero LA 2013 Estrogen receptor $\beta$ growth-inhibitory effects are repressed through activation of MAPK and PI3K signalling in mammary epithelial and breast cancer cells. Oncogene 32 2390-2402. (doi:10.1038/ onc.2012.261)

Couse J \& Korach K 1999 Estrogen receptor null mice: what have we learned and where will they lead us? Endocrine Reviews 20 358-417. (doi:10.1210/er.20.3.358)

Cvoro A, Tatomer D, Tee M, Zogovic T, Harris H \& Leitman D 2008 Selective estrogen receptor- $\beta$ agonists repress transcription of proinflammatory genes. Journal of Immunology 180 630-636.

Deblois G \& Giguere V 2013 Oestrogen-related receptors in breast cancer: control of cellular metabolism and beyond. Nature Reviews. Cancer $\mathbf{1 3}$ 27-36. (doi:10.1038/nrc3396)

DuSell CD \& McDonnell DP 2008 27-Hydroxycholesterol: a potential endogenous regulator of estrogen receptor signaling. Trends in Pharmacological Sciences 29 510-514. (doi:10.1016/j.tips.2008.07.003)

Esslimani-Sahla M, Simony-Lafontaine J, Kramar A, Lavaill R, Mollevi C, Warner M, Gustafsson J-A \& Rochefort H 2004 Estrogen receptor $\beta$ (ER $\beta$ ) level but not its ER $\beta$-cx variant helps to predict tamoxifen resistance in breast cancer. Clinical Cancer Research 10 5769-5776. (doi:10.1158/ 1078-0432.CCR-04-0389)

Feng Y, Manka D, Wagner KU \& Khan SA 2007 Estrogen receptor- $\alpha$ expression in the mammary epithelium is required for ductal and alveolar morphogenesis in mice. PNAS 104 14718-14723. (doi:10.1073/pnas.0706933104)

Finan B, Yang B, Ottaway N, Stemmer K, Muller TD, Yi CX, Habegger K, Schriever SC, Garcia-Caceres C, Kabra DG et al. 2012 Targeted estrogen delivery reverses the metabolic syndrome. Nature Medicine 18 1847-1856. (doi:10.1038/nm.3009)
Fisher B, Costantino J, Wickerham D, Cecchini R, Cronin W, Robidoux A, Bevers T, Kavanah M, Atkins J, Margolese R et al. 2005 Tamoxifen for the prevention of breast cancer: current status of the National Surgical Adjuvant Breast and Bowel Project P-1 study. Journal of the National Cancer Institute 97 1652-1662. (doi:10.1093/jnci/dji372)

Fleming F, Hill A, McDermott E, O’Higgins N \& Young L 2004 Differential recruitment of coregulator proteins steroid receptor coactivator-1 and silencing mediator for retinoid and thyroid receptors to the estrogen receptor-estrogen response element by $\beta$-estradiol and 4-hydroxytamoxifen in human breast cancer. Journal of Clinical Endocrinology and Metabolism 89 375-383. (doi:10.1210/jc.2003031048)

Forster C, Makela S, Warri A, Kietz S, Becker D, Hultenby K, Warner M \& Gustafsson J 2002 Involvement of estrogen receptor b in terminal differentiation of mammary gland epithelium. PNAS 99 15578-15583. (doi:10.1073/pnas.192561299)

Fox E, Davis R \& Shupnik M 2008 ER $\beta$ in breast cancer - onlooker, passive player, or active protector? Steroids 73 1039-1051. (doi:10.1016/ j.steroids.2008.04.006)

Giroux V, Lemay F, Bernatchez G, Robitaille Y \& Carrier J 2008 Estrogen receptor $\beta$ deficiency enhances small intestinal tumorigenesis in ApcMin/+ mice. International Journal of Cancer 123 303-311. (doi:10.1002/ijc.23532)

Grober OM, Mutarelli M, Giurato G, Ravo M, Cicatiello L, De Filippo MR, Ferraro L, Nassa G, Papa MF, Paris O et al. 2011 Global analysis of estrogen receptor $\beta$ binding to breast cancer cell genome reveals an extensive interplay with estrogen receptor $\alpha$ for target gene regulation. BMC Genomics 12 36. (doi:10.1186/1471-2164-12-36)

Gruvberger-Saal S, Bendahl P, Saal L, Laakso M, Hegardt C, Edén P, Peterson C, Malmström P, Isola J, Borg A et al. 2007 Estrogen receptor $\beta$ expression is associated with tamoxifen response in ER $\alpha$-negative breast carcinoma. Clinical Cancer Research 13 1987-1994. (doi:10.1158/ 1078-0432.CCR-06-1823)

Guerini V, Sau D, Scaccianoce E, Rusmini P, Ciana P, Maggi A, Martini P, Katzenellenbogen B, Martini L, Motta M et al. 2005 The androgen derivative $5 \alpha$-androstane- $3 \beta, 17 \beta$-diol inhibits prostate cancer cell migration through activation of the estrogen receptor $\beta$ subtype. Cancer Research 65 5445-5453. (doi:10.1158/0008-5472.CAN-04-1941)

Hall J, Couse J \& Korach K 2001 The multifaceted mechanisms of estradiol and estrogen receptor signaling. Journal of Biological Chemistry 276 36869-36872. (doi:10.1074/jbc.R100029200)

Hamilton-Burke W, Coleman L, Cummings M, Green CA, Holliday DL, Horgan K, Maraqa L, Peter MB, Pollock S, Shaaban AM et al. 2010 Phosphorylation of estrogen receptor $\beta$ at serine 105 is associated with good prognosis in breast cancer. American Journal of Pathology 177 1079-1086. (doi:10.2353/ajpath.2010.090886)

Hammes SR \& Levin ER 2011 Minireview: recent advances in extranuclear steroid receptor actions. Endocrinology 152 4489-4495. (doi:10.1210/ en.2011-1470)

Hammond ME, Hayes DF, Dowsett M, Allred DC, Hagerty KL, Badve S, Fitzgibbons PL, Francis G, Goldstein NS, Hayes M et al. 2010 American Society of Clinical Oncology/College Of American Pathologists guideline recommendations for immunohistochemical testing of estrogen and progesterone receptors in breast cancer. Journal of Clinical Oncology 28 2784-2795. (doi:10.1200/JCO.2009.25.6529)

Haring J, Schuler S, Lattrich C, Ortmann O \& Treeck O 2012 Role of estrogen receptor $\beta$ in gynecological cancer. Gynecologic Oncology 127 673-676. (doi:10.1016/j.ygyno.2012.09.006)

Harrington W, Sheng S, Barnett D, Petz L, Katzenellenbogen J \& Katzenellenbogen B 2003 Activities of estrogen receptor $\alpha$ - and $\beta$-selective ligands at diverse estrogen responsive gene sites mediating transactivation or transrepression. Molecular and Cellular Endocrinology 206 13-22. (doi:10.1016/S0303-7207(03)00255-7)

Helguero LA, Faulds MH, Gustafsson JA \& Haldosen LA 2005 Estrogen receptors alfa $(\mathrm{ER} \alpha)$ and $\beta(\mathrm{ER} \beta)$ differentially regulate proliferation and 
apoptosis of the normal murine mammary epithelial cell line HC11. Oncogene 24 6605-6616. (doi:10.1038/sj.onc.1208807)

Herynk M \& Fuqua S 2004 Estrogen receptor mutations in human disease. Endocrine Reviews 25 869-898. (doi:10.1210/er.2003-0010)

Hickey TE, Robinson JL, Carroll JS \& Tilley WD 2012 Minireview: the androgen receptor in breast tissues: growth inhibitor, tumor suppressor, oncogene? Molecular Endocrinology 26 1252-1267. (doi:10.1210/me.2012-1107)

Hodges-Gallagher L, Valentine CD, El Bader S \& Kushner PJ 2008 Estrogen receptor $\beta$ increases the efficacy of antiestrogens by effects on apoptosis and cell cycling in breast cancer cells. Breast Cancer Research and Treatment 109 241-250. (doi:10.1007/s10549-007-9640-6)

Honma N, Horii R, Iwase T, Saji S, Younes M, Takubo K, Matsuura M, Ito Y, Akiyama F \& Sakamoto G 2008 Clinical importance of estrogen receptor- $\beta$ evaluation in breast cancer patients treated with adjuvant tamoxifen therapy. Journal of Clinical Oncology 26 3727-3734. (doi:10.1200/JCO.2007.14.2968)

Hou Y, Yuan S, Li H, Wu J, Lu J, Liu G, Lu L, Shen Z, Ding J \& Shao Z 2004 ER $\beta$ exerts multiple stimulative effects on human breast carcinoma cells. Oncogene 23 5799-5806. (doi:10.1038/sj.onc.1207765)

Kuiper G, Enmark E, Pelto-Huikko M, Nilsson S \& Gustafsson J-A 1996 Cloning of a novel estrogen receptor expressed in rat prostate and ovary. PNAS 93 5925-5930. (doi:10.1073/pnas.93.12.5925)

Kuiper G, Lemmen J, Carlsson B, Corton J, Safe S \& Saag PVD 1998 Interaction of estrogenic chemicals and phytoestrogens with estrogen receptor $\beta$. Endocrinology 139 4252-4263. (doi:10.1210/ en.139.10.4252)

Kumar R \& McEwan IJ 2012 Allosteric modulators of steroid hormone receptors: structural dynamics and gene regulation. Endocrine Reviews 33 271-299. (doi:10.1210/er.2011-1033)

Lazennec G, Bresson D, Lucas A, Chauveau C \& Vignon F 2001 ERb inhibits proliferation and invasion of breast cancer cells. Endocrinology 142 4120-4130. (doi:10.1210/en.142.9.4120)

Le Romancer M, Poulard C, Cohen P, Sentis S, Renoir JM \& Corbo L 2011 Cracking the estrogen receptor's posttranslational code in breast tumors. Endocrine Reviews 32 597-622. (doi:10.1210/er.2010-0016)

Leung Y, Mak P, Hassan S \& Ho S 2006 Estrogen receptor (ER)- $\beta$ isoforms: a key to understanding ER- $\beta$ signaling. PNAS 103 13162-13167. (doi:10.1073/pnas.0605676103)

Leung YK, Lee MT, Lam HM, Tarapore P \& Ho SM 2012 Estrogen receptor- $\beta$ and breast cancer: translating biology into clinical practice. Steroids $\mathbf{7 7}$ 727-737. (doi:10.1016/j.steroids.2012.03.008)

Levin ER 2012 Elusive extranuclear estrogen receptors in breast cancer. Clinical Cancer Research 18 6-8. (doi:10.1158/1078-0432.CCR-11-2547)

Levin ER \& Pietras RJ 2008 Estrogen receptors outside the nucleus in breast cancer. Breast Cancer Research and Treatment 108 351-361. (doi:10.1007/s10549-007-9618-4)

Lewandowski S, Thiery J, Jalil A, Leclercq G, Szczylik C \& Chouaib S 2005 Opposite effects of estrogen receptors $\alpha$ and $\beta$ on MCF-7 sensitivity to the cytotoxic action of TNF and p53 activity. Oncogene 24 4789-4798. (doi:10.1038/sj.onc.1208595)

Leygue E \& Murphy L 2011 Comparative evaluation of ERa and ERb significance in breast cancer: state of the art. Expert Review of Endocrinology \& Metabolism 6 333-343. (doi:10.1586/eem.11.27)

Leygue E, Dotzlaw H, Watson P \& Murphy L 1998 Altered estrogen receptor $\alpha$ and $\beta$ mRNA expression during human breast tumorigenesis. Cancer Research 58 3197-3201.

Leygue E, Dotzlaw H, Watson P \& Murphy L 1999 Expression of estrogen receptor $\beta 1, \beta 2$, and $\beta 5$ messenger RNAs in human breast tissue. Cancer Research 59 1175-1179.

Liu Y, Gao H, Marstrand TT, Strom A, Valen E, Sandelin A, Gustafsson JA \& Dahlman-Wright K 2008 The genome landscape of ER $\alpha$ - and ERß-binding DNA regions. PNAS 105 2604-2609. (doi:10.1073/ pnas.0712085105)
Lonard DM, Lanz RB \& O'Malley BW 2007 Nuclear receptor coregulators and human disease. Endocrine Reviews 28 575-587. (doi:10.1210/ er.2007-0012)

von Maillot K, Gentsch HH \& Gunselmann W 1980 Steroid receptors and response to endocrine treatment and chemotherapy of advanced breast cancer. Journal of Cancer Research and Clinical Oncology 98 301-313. (doi:10.1007/BF00410792)

Mak P, Leav I, Pursell B, Bae D, Yang X, Taglienti CA, Gouvin LM, Sharma VM \& Mercurio AM 2010 ER $\beta$ impedes prostate cancer EMT by destabilizing HIF- $1 \alpha$ and inhibiting VEGF-mediated snail nuclear localization: implications for Gleason grading. Cancer Cell $\mathbf{1 7}$ 319-332. (doi:10.1016/j.ccr.2010.02.030)

Mak P, Chang C, Pursell B \& Mercurio AM 2013 Estrogen receptor $\beta$ sustains epithelial differentiation by regulating prolyl hydroxylase 2 transcription. PNAS 110 4708-4713. (doi:10.1073/pnas.1221654110)

McKenna N, Lanz R \& O'Malley B 1999 Nuclear receptor coregulators: cellular and molecular biology. Endocrine Reviews 20 321-344. (doi:10.1210/er.20.3.321)

Michael Miller KK, Al-Rayyan N, Ivanova MM, Mattingly KA, Ripp SL, Klinge CM \& Prough RA 2012 DHEA metabolites activate estrogen receptors $\alpha$ and $\beta$. Steroids 78 15-25. (doi:10.1016/j.steroids. 2012.10.002)

Miller W, Anderson T, Dixon J \& Saunders P 2006 Oestrogen receptor $\beta$ and neoadjuvant therapy with tamoxifen: prediction of response and effects of treatment. British Journal of Cancer 94 1333-1338. (doi:10.1038/sj.bjc.6603082)

Monroe D, Secreto F, Subramaniam M, Getz B, Khosla S \& Spelsberg T 2005 Estrogen receptor $\alpha$ and $\beta$ heterodimers exert unique effects on estrogen- and tamoxifen-dependent gene expression in human U2OS osteosarcoma cells. Molecular Endocrinology 19 1555-1568. (doi:10.1210/me.2004-0381)

Murphy L \& Watson P 2006 Is oestrogen receptor- $\beta$ a predictor of endocrine therapy responsiveness in human breast cancer? Endocrine-Related Cancer 13 327-334. (doi:10.1677/erc.1.01141)

Murphy LC \& Leygue E 2012 The role of estrogen receptor- $\beta$ in breast cancer. Seminars in Reproductive Medicine 30 5-13. (doi:10.1055/s-00311299592)

Murphy L, Cherlet T, Lewis A, Banu Y \& Watson P 2003 New insights into estrogen receptor function in human breast cancer. Annals of Medicine 35 614-631. (doi:10.1080/07853890310014579)

Murphy L, Peng B, Lewis A, Davie J, Leygue E, Kemp A, Ung K, Vendetti M \& Shiu R 2005 Inducible upregulation of oestrogen receptor- $\beta 1$ affects oestrogen and tamoxifen responsiveness in MCF7 human breast cancer cells. Journal of Molecular Endocrinology 34 553-566. (doi:10.1677/ jme.1.01688)

Muscat GE, Eriksson NA, Byth K, Loi S, Graham D, Jindal S, Davis MJ, Clyne C, Funder JW, Simpson ER et al. 2013 Research resource: nuclear receptors as transcriptome: discriminant and prognostic value in breast cancer. Molecular Endocrinology 27 350-365. (doi:10.1210/ me.2012-1265)

Nassa G, Tarallo R, Ambrosino C, Bamundo A, Ferraro L, Paris O, Ravo M, Guzzi PH, Cannataro M, Baumann M et al. 2011 A large set of estrogen receptor $\beta$-interacting proteins identified by tandem affinity purification in hormone-responsive human breast cancer cell nuclei. Proteomics 11 159-165. (doi:10.1002/pmic.201000344)

Ni M, Chen Y, Lim E, Wimberly H, Bailey ST, Imai Y, Rimm DL, Liu XS \& Brown M 2011 Targeting androgen receptor in estrogen receptornegative breast cancer. Cancer Cell 20 119-131. (doi:10.1016/j.ccr. 2011.05.026)

Novelli F, Milella M, Melucci E, Di Benedetto A, Sperduti I, PerroneDonnorso R, Perracchio L, Venturo I, Nistico C, Fabi A et al. 2008 A divergent role for estrogen receptor- $\beta$ in node-positive and nodenegative breast cancer classified according to molecular subtypes: an observational prospective study. Breast Cancer Research 10 R74. (doi:10.1186/bcr2139) 
Ogawa S, Inoue S, Watanabe T, Orimo A, Hosoi T, Ouchi Y \& Muramatsu M 1998 Molecular cloning and characterization of human estrogen receptor bcx: potential inhibitor of estrogen action in human. Nucleic Acids Research 26 3505-3512. (doi:10.1093/nar/26.15.3505)

O'Neill P, Davies M, Shaaban A, Innes H, Torevell A, Sibson D \& Foster C 2004 Wild-type oestrogen receptor $\beta$ (ER $\beta 1)$ mRNA and protein expression in Tamoxifen-treated post-menopausal breast cancers. British Journal of Cancer 91 1694-1702.

Paech K, Webb P, Kuiper G, Nilsson S, Gustafsson J, Kushner PJ \& Scanlan TS 1997 Differential ligand activation of estrogen receptors $\mathrm{ER} \alpha$ and ER $\beta$ at AP1 sites. Science 277 1508-1510. (doi:10.1126/ science.277.5331.1508)

Palmieri G, Cheng G, Saji S, Zelada-Hedman M, Warri A, Weihua Z, Noorden AV, Wahlstrom T, Coombes R, Warner M et al. 2002 Estrogen receptor $\beta$ in breast cancer. Endocrine-Related Cancer 9 1-13. (doi:10.1677/erc.0.0090001)

Paruthiyil S, Parmar H, Kerekatte V, Cunha G, Firestone G \& Leitman D 2004 Estrogen receptor $b$ inhibits human breast cancer cell proliferation and tumor formation by causing a G2 cell cycle arrest. Cancer Research 64 423-428. (doi:10.1158/0008-5472.CAN-03-2446)

Paruthiyil S, Cvoro A, Tagliaferri M, Cohen I, Shtivelman E \& Leitman DC 2011 Estrogen receptor $\beta$ causes a G2 cell cycle arrest by inhibiting CDK1 activity through the regulation of cyclin B1, GADD45A, and BTG2. Breast Cancer Research and Treatment 129 777-784. (doi:10.1007/ s10549-010-1273-5)

Pedram A, Razandi M, Wallace D \& Levin E 2006 Functional estrogen receptors in the mitochondria of breast cancer cells. Molecular Biology of the Cell 17 2125-2137. (doi:10.1091/mbc.E05-11-1013)

Peng B, Lu B, Leygue E \& Murphy L 2003 Putative functional characteristics of human estrogen receptor- $\beta$ isoforms. Journal of Molecular Endocrinology 30 13-29. (doi:10.1677/jme.0.0300013)

Picard N, Caron V, Bilodeau S, Sanchez M, Mascle X, Aubry M \& Tremblay A 2012 Identification of estrogen receptor $\beta$ as a SUMO-1 target reveals a novel phosphorylated sumoylation motif and regulation by glycogen synthase kinase 3ß. Molecular and Cellular Biology 32 2709-2721. (doi:10.1128/MCB.06624-11)

Powell E, Shanle E, Brinkman A, Li J, Keles S, Wisinski KB, Huang W \& Xu W 2012 Identification of estrogen receptor dimer selective ligands reveals growth-inhibitory effects on cells that co-express ER $\alpha$ and ER $\beta$. PLoS ONE 7 e30993. (doi:10.1371/journal.pone.0030993)

Prins GS \& Korach KS 2008 The role of estrogens and estrogen receptors in normal prostate growth and disease. Steroids 73 233-244. (doi:10.1016/ j.steroids.2007.10.013)

Rae JM, Creighton CJ, Meck JM, Haddad BR \& Johnson MD 2007 MDA-MB435 cells are derived from M14 melanoma cells - a loss for breast cancer, but a boon for melanoma research. Breast Cancer Research and Treatment 104 13-19. (doi:10.1007/s10549-006-9392-8)

Razandi M, Pedram A, Jordan VC, Fuqua S \& Levin ER 2012 Tamoxifen regulates cell fate through mitochondrial estrogen receptor $\beta$ in breast cancer. Oncogene [in press]. (doi:10.1038/onc.2012.335)

Roger P, Sahla M, Makela S, Gustafsson JA, Baldet P \& Rochefort H 2001 Decreased expression of estrogen receptor $\beta$ protein in proliferative preinvasive mammary tumors. Cancer Research 61 2537-2541.

Rousseau C, Nichol J, Pettersson F, Couture M \& Miller W 2004 ER $\beta$ sensitizes breast cancer cells to retinoic acid: evidence of transcriptional crosstalk. Molecular Cancer Research 2 523-531.

Saijo K, Collier JG, Li AC, Katzenellenbogen JA \& Glass CK 2011 An ADIOL-ER $\beta$-CtBP transrepression pathway negatively regulates microglia-mediated inflammation. Cell 145 584-595. (doi:10.1016/ j.cell.2011.03.050)

Saji S, Jensen E, Nilsson S, Rylander T, Warner M \& Gustafsson J-A 2000 Estrogen receptors $\mathrm{a}$ and $\mathrm{b}$ in the rodent mammary gland. PNAS $\mathbf{9 7}$ 337-342. (doi:10.1073/pnas.97.1.337)

Saji S, Omoto Y, Shimizu C, Horiguchi S, Watanabe T, Funata N, Hayash S, Gustafsson J \& Toi M 2002a Clinical impact of assay of estrogen receptor $\beta \mathrm{cx}$ in breast cancer. Breast Cancer Research and Treatment 9 303-307.

Saji S, Omoto Y, Shimizu C, Warner M, Hayashi Y, Horiguchi S, Watanabe T, Hayashi S \& Gustafsson J $2002 b$ Expression of estrogen receptor (ER) $(\beta) \mathrm{cx}$ protein in $\mathrm{ER}(\alpha)$-positive breast cancer: specific correlation with progesterone receptor. Cancer Research 62 4849-4853.

Sanchez M, Picard N, Sauve K \& Tremblay A 2010 Challenging estrogen receptor $\beta$ with phosphorylation. Trends in Endocrinology and Metabolism 21 104-110. (doi:10.1016/j.tem.2009.09.007)

Sanchez M, Picard N, Sauve K \& Tremblay A 2012 Coordinate regulation of estrogen receptor $\beta$ degradation by Mdm 2 and CREB-binding protein in response to growth signals. Oncogene 32 117-126. (doi:10.1038/ onc.2012.19)

Savinov A, Remacle A, Golubkov V, Krajewska M, Kennedy S, Duffy M, Rozanov D, Krajewski S \& Strongin A 2006 Matrix metalloproteinase 26 proteolysis of the $\mathrm{NH} 2$-terminal domain of the estrogen receptor $\beta$ correlates with the survival of breast cancer patients. Cancer Research 66 2716-2724. (doi:10.1158/0008-5472.CAN-05-3592)

Secreto FJ, Monroe DG, Dutta S, Ingle JN \& Spelsberg TC 2007 Estrogen receptor $\alpha / \beta$ isoforms, but not $\beta \mathrm{cx}$, modulate unique patterns of gene expression and cell proliferation in Hs578T cells. Journal of Cellular Biochemistry 101 1125-1147. (doi:10.1002/jcb.21205)

Shaaban AM, Green AR, Karthik S, Alizadeh Y, Hughes TA, Harkins L, Ellis IO, Robertson JF, Paish EC, Saunders PT et al. 2008 Nuclear and cytoplasmic expression of ER $\beta 1, \mathrm{ER} \beta 2$, and ER $\beta 5$ identifies distinct prognostic outcome for breast cancer patients. Clinical Cancer Research 14 5228-5235. (doi:10.1158/1078-0432.CCR-07-4528)

Shanle EK \& Xu W 2010 Selectively targeting estrogen receptors for cancer treatment. Advanced Drug Delivery Reviews 62 1265-1276. (doi:10.1016/ j.addr.2010.08.001)

Shanle EK, Hawse JR \& Xu W 2011 Generation of stable reporter breast cancer cell lines for the identification of ER subtype selective ligands. Biochemical Pharmacology 82 1940-1949. (doi:10.1016/j.bcp. 2011.08.026)

Skliris G, Leygue E, Curtis-Snell L, Watson P \& Murphy L 2006 Expression of oestrogen receptor- $\beta$ in oestrogen receptor- $\alpha$ negative human breast tumours. British Journal of Cancer 95 616-626. (doi:10.1038/sj.bjc. 6603295)

Skliris G, Lewis A, Emberley E, Peng B, Weebadda W, Kemp A, Davie J, Shiu R, Watson P, Murphy L et al. 2007 Estrogen receptor- $\beta$ regulates psoriasin (S100A7) in human breast cancer. Breast Cancer Research and Treatment 104 75-85. (doi:10.1007/s10549-006-9390-x)

Skliris GP, Nugent ZJ, Rowan BG, Penner CR, Watson PH \& Murphy LC 2010 A phosphorylation code for oestrogen receptor- $\alpha$ predicts clinical outcome to endocrine therapy in breast cancer. Endocrine-Related Cancer 17 589-597. (doi:10.1677/ERC-10-0030)

Speirs V, Skliris G, Burdall S \& Carder P 2002 Distinct expression patterns of $\mathrm{ERa}$ and $\mathrm{ERb}$ in normal human mammary gland. Journal of Clinical Pathology 255 371-374. (doi:10.1136/jcp.55.5.371)

Stewart J, King R, Hayward J \& Rubens R 1982 Estrogen and progesterone receptors: correlation of response rates, site and timing of receptor analysis. Breast Cancer Research and Treatment 2 243-250. (doi:10.1007/ BF01806937)

Strom A, Hartman J, Foster J, Kietz S, Wimalasena J \& Gustafsson J-A 2004 Estrogen receptor $\mathrm{b}$ inhibits $17 \mathrm{~b}$-estradiol-stimulated proliferation of the breast cancer cell line T-47D. PNAS 101 1566-1571. (doi:10.1073/ pnas.0308319100)

Tateishi Y, Sonoo R, Sekiya Y, Sunahara N, Kawano M, Wayama M, Hirota R, Kawabe Y, Murayama A, Kato S et al. 2006 Turning off estrogen receptor $\beta$-mediated transcription requires estrogen-dependent receptor proteolysis. Molecular and Cellular Biology 26 7966-7976. (doi:10.1128/ MCB.00713-06)

Thomas C \& Gustafsson JA 2011 The different roles of ER subtypes in cancer biology and therapy. Nature Reviews. Cancer 11 597-608. (doi:10.1038/ nrc3093) 
Thomas C \& Gustafsson JA 2012 Targeting PES1 for restoring the ER $\alpha /$ ER $\beta$ ratio in breast cancer. Journal of Clinical Investigation 122 2771-2773. (doi:10.1172/JCI65133)

Thomas C, Rajapaksa G, Nikolos F, Hao R, Katchy A, McCollum CW, Bondesson M, Quinlan P, Thompson A, Krishnamurthy S et al. 2012 ER $\beta 1$ represses basal breast cancer epithelial to mesenchymal transition by destabilizing EGFR. Breast Cancer Research 14 R148. (doi:10.1186/ bcr3358)

Tonetti D, Rubenstein R, Deleon M, Zhao H, Pappas S, Bentrem D, Chen B, Constantinou A \& Jordan V 2003 Stable transfection of an estrogen receptor $\beta$ cDNA isoform into MDAMB231 breast cancer cells. Journal of Steroid Biochemistry and Molecular Biology 87 47-55. (doi:10.1016/ j.jsbmb.2003.07.003)

Treeck O, Lattrich C, Springwald A \& Ortmann O 2010 Estrogen receptor $\beta$ exerts growth-inhibitory effects on human mammary epithelial cells. Breast Cancer Research and Treatment 120 557-565. (doi:10.1007/ s10549-009-0413-2)

Trialists' EBC 1992 Systemic treatment of early breast cancer by hormonal, cytotoxic, or immune therapy, 133 randomised trials involving 31000 recurrences and 24000 deaths among 75000 women. Early Breast Cancer Trialists'. Lancet 339 1-15.

Trialists' EBC 1998 Tamoxifen for early breast cancer: an overview of the randomised trials. Early Breast Cancer Trialists' Collaborative Group. Lancet 351 1451-1467. (doi:10.1016/S0140-6736(97)11423-4)

Vivar OI, Zhao X, Saunier EF, Griffin C, Mayba OS, Tagliaferri M, Cohen I, Speed TP \& Leitman DC 2010 Estrogen receptor $\beta$ binds to and regulates three distinct classes of target genes. Journal of Biological Chemistry $\mathbf{2 8 5}$ 22059-22066. (doi:10.1074/jbc.M110.114116)

Weihua Z, Saji S, Makinen S, Cheng G, Jensen E, Warner M \& Gustaffson J-A 2000 Estrogen receptor (ER) b, a modulator of ERa in the uterus. PNAS 97 5936-5941. (doi:10.1073/pnas.97.11.5936)

Welsh AW, Lannin DR, Young GS, Sherman ME, Figueroa JD, Henry NL, Ryden L, Kim C, Love RR, Schiff R et al. 2012 Cytoplasmic estrogen receptor in breast cancer. Clinical Cancer Research 18 118-126. (doi:10.1158/1078-0432.CCR-11-1236)
Williams C, Edvardsson K, Lewandowski SA, Strom A \& Gustafsson JA 2008 A genome-wide study of the repressive effects of estrogen receptor $\beta$ on estrogen receptor $\alpha$ signaling in breast cancer cells. Oncogene $\mathbf{2 7}$ 1019-1032. (doi:10.1038/sj.onc.1210712)

Wu X, Subramaniam M, Grygo SB, Sun Z, Negron V, Lingle WL, Goetz MP, Ingle JN, Spelsberg TC \& Hawse JR 2011 Estrogen receptor- $\beta$ sensitizes breast cancer cells to the anti-estrogenic actions of endoxifen. Breast Cancer Research 13 R27. (doi:10.1186/bcr2844)

Yan M, Rayoo M, Takano EA \& Fox SB 2011 Nuclear and cytoplasmic expressions of ER $\beta 1$ and ER $\beta 2$ are predictive of response to therapy and alters prognosis in familial breast cancers. Breast Cancer Research and Treatment 126 395-405. (doi:10.1007/ s10549-010-0941-9)

Yan Y, Li X, Blanchard A, Bramwell VHC, Pritchard KI, Tu D, Shepherd L, Myal Y, Penner C, Watson PH et al. 2013 Expression of both estrogen receptor- $\beta 1$ (ER- $\beta 1$ ) and its co-regulator steroid receptor RNA activator protein (SRAP) are predictive for benefit from tamoxifen therapy in patients with estrogen receptor- $\alpha(\mathrm{ER}-\alpha)$ negative early breast cancer (EBC). Annals of Oncology [in press]. (doi:10.1093/annonc/ mdt132)

Zhao C, Matthews J, Tujague M, Wan J, Strom A, Toresson G, Lam EW, Cheng G, Gustafsson JA \& Dahlman-Wright K 2007 Estrogen receptor $\beta 2$ negatively regulates the transactivation of estrogen receptor $\alpha$ in human breast cancer cells. Cancer Research 67 3955-3962. (doi:10.1158/ 0008-5472.CAN-06-3505)

Zhao C, Gao H, Liu Y, Papoutsi Z, Jaffrey S, Gustafsson JA \& DahlmanWright K 2010 Genome-wide mapping of estrogen receptor- $\beta$-binding regions reveals extensive cross-talk with transcription factor activator protein-1. Cancer Research 70 5174-5183. (doi:10.1158/0008-5472. CAN-09-4407)

Zwart W, Theodorou V \& Carroll JS 2011 Estrogen receptor-positive breast cancer: a multidisciplinary challenge. Wiley Interdisciplinary Reviews. Systems Biology and Medicine 3 216-230. (doi:10.1002/ wsbm.109)

Received in final form 19 March 2013

Accepted 25 March 2013

Made available online as an Accepted Preprint

26 March 2013 http://erc.endocrinology-journals.org DOI: 10.1530/ERC-12-0389
(C) 2013 Society for Endocrinology Printed in Great Britain 